\title{
Spontaneous secretion of interferon $\gamma$ and interleukin 4 by human intraepithelial and lamina propria gut lymphocytes
}

\author{
M Carol`, A Lambrechts`, A Van Gossum, M Libin, M Goldman, F Mascart-Lemone
}

${ }^{\star} \mathrm{M}$ Carol and $\mathrm{A}$ Lambrechts contributed equally to this work
Department of Immunology, Hôpital Erasme, Université Libre de Bruxelles, Belgium

M Carol

A Lambrechts

M Libin

$M$ Goldman

F Mascart-Lemone

Department of Gastroenterology A Van Gossum

Correspondence to: Dr F Mascart-Lemone, Department of Immunology, Hôpital Erasme, 808 route de Lennik, B-1070 Brussels, Belgium.

Accepted for publication 26 November 1997
Abstract

Background-Cytokines secreted by intestinal $T$ lymphocytes probably play a critical role in regulation of the gut associated immune responses.

Aims-To quantify interferon $\gamma($ IFN- $\gamma)$ and interleukin 4 (IL-4) secreting cells (SC) among human intraepithelial (IEL) and lamina propria (LPL) lymphocytes from the duodenum and right colon in non-pathological situations and in the absence of in vitro stimulation.

Patients-Duodenal and right colonic biopsy specimens were obtained from patients with no inflammation of the intestinal mucosa.

Methods-Intraepithelial and lamina propria cell suspensions were assayed for numbers of cells spontaneously secreting IFN- $\gamma$ and IL-4 by a two site reverse enzyme linked immunospot technique (ELISPOT).

Results-The relatively high proportion of duodenal lymphocytes spontaneously secreting IFN- $\gamma$ (IEL 3.6\%; LPL 1.9\%) and IL-4 (IEL 1.3\%; LPL $0.7 \%$ ) contrasted with the very low numbers of spontaneously IFN- $\gamma$ SC and the absence of spontaneously IL-4 SC among peripheral blood mononuclear cells. In the basal state, both IFN- $\gamma$ and IL-4 were mainly produced by $\mathrm{CD}^{+}$cells. Within the colon, only $0.2 \%$ of IEL and LPL secreted IFN- $\gamma$ in the basal state, and $0.1 \%$ secreted IL-4.

Conclusions-Compared with peripheral lymphocytes substantial proportions of intestinal epithelial and lamina propria lymphocytes spontaneously secrete IFN- $\gamma$ and/or IL-4. These cytokines are probably involved in the normal homoeostasis of the human intestinal mucosa. Disturbances in their secretion could play a role in the pathogenesis of gastrointestinal diseases.

(Gut 1998;42:643-649)

Keywords: intestinal lymphocytes; ELISPOT; interferon $\gamma$; interleukin 4

The bowel mucosa is constantly exposed to numerous antigenic substances, especially food derived proteins in the jejunum and microbial products in the colon. In order to maintain the integrity of the intestinal epithelium, the gut associated immune system must develop efficient responses against pathogenic microorganisms and prevent sensitisation to food anti- gens and commensal microbial flora. Cytokines locally produced by $\mathrm{T}$ lymphocytes probably play critical roles in the complex regulation of immune and non-immune responses at the intestinal level. Indeed, interferon $\gamma$ (IFN- $\gamma$ ) was found in some studies to be constitutively expressed by human intraepithelial ${ }^{1}$ or lamina propria lymphocytes ${ }^{23}$ or both, ${ }^{4}$ and to control basic physiological functions of the intestinal epithelium, including the secretion and uptake of electrolytes ${ }^{5}$ and the transport of potentially protective immunoglobulins. ${ }^{6}$ Interferon $\gamma$ is endowed with proinflammatory properties and its synthesis and action are usually tightly controlled. ${ }^{7}$ Interleukin 10 (IL-10) and IL-4 are two major candidates for such regulatory control of IFN $-\gamma^{8}$ The inflammatory bowel disease occurring in IL-10 deficient mice indicates that a major physiological role of IL-10 is to prevent the development of intestinal inflammation. ${ }^{9}$

Although IL-4 was found to be synthesised by lamina propria intestinal lymphocytes after in vitro polyclonal activation, ${ }^{10} 11$ the secretion of this cytokine in the gut under physiological conditions is a matter of controversy. ${ }^{12}{ }^{13}$ In the present study, we used a sensitive enzyme linked immunospot technique (ELISPOT) to enumerate IFN- $\gamma$ secreting cells (SC) and IL-4 SC among intraepithelial lymphocytes (IEL) and lamina propria lymphocytes (LPL) directly obtained from normal biopsy specimens of duodenum and right colon. As higher numbers of IFN- $\gamma$ SC and IL-4 SC were found in the duodenum than in the colon, further experiments to characterise the $\mathrm{T}$ cell population responsible for the spontaneous synthesis of these cytokines in the gut associated immune system were conducted on duodenal biopsy specimens.

\section{Materials and methods}

PATIENTS AND SAMPLES

Intestinal biopsy specimens were obtained from 33 control adult patients (mean age 49 years, range 33-66) undergoing intestinal endoscopy for investigation of dyspeptic complaints or for cancer screening. Duodenal biopsy specimens from 19 patients and right colonic biopsy specimens from 14 patients were analysed. Only the specimens taken from macroscopically unaffected mucosa and with no evidence of microscopic inflammation after histological analysis were included in this study. For each patient, seven biopsy specimens were taken, and transported within one hour in $\mathrm{Ca}^{++} / \mathrm{Mg}^{++}$free Hank's buffered salt solution 
(HBSS, Gibco, Life Technology, Paisley, Scotland, UK) to the laboratory. One specimen was fixed in formalin for routine histological examination, and the other six were processed for IEL and LPL isolations. Venous blood samples were collected from 20 patients.

Informed consent was obtained from all patients and this study was approved by the Research Ethics Committee of the Medical Faculty of the Université Libre de Bruxelles.

ISOLATION OF IEL, LPL, AND PERIPHERAL BLOOD MONONUCLEAR CELLS

The biopsy specimens were first extensively washed in $\mathrm{Ca}^{++} / \mathrm{Mg}^{++}$free HBSS containing $0.02 \%$ penicillin-streptomycin and $40 \mu \mathrm{g} / \mathrm{ml}$ gentamycin. Epithelial cells (IEL and enterocytes) were then obtained using a modification of a previously described protocol. ${ }^{14}$ Briefly, the biopsy specimens were incubated for one hour under stirring at $37^{\circ} \mathrm{C}$ with $1 \mathrm{mM}$ EDTA (Sigma Chemical Co., St Louis, Missouri, USA) in Iscove's medium (Gibco) supplemented with $40 \mu \mathrm{g} / \mathrm{ml}$ gentamycin, $10 \%$ fetal calf serum (FCS), and $50 \mu \mathrm{M}$ 2-mercaptoethanol. Extracted cells (IEL plus enterocytes) were collected by decanting them after tissue fragments had settled; they were washed once in HBSS at $600 \mathrm{~g}$ for 10 minutes, and resuspended in supplemented Iscove's medium. Histological examination of the remaining fragment revealed that the villous and lamina propria structures were still preserved at that time.

Subsequently, lamina propria cells were obtained by a standard procedure in which the remaining biopsy fragments were first cut into approximately $1 \times 1 \mathrm{~mm}$ fragments and then incubated while stirring at $37^{\circ} \mathrm{C}$ for 45 minutes in Iscove's medium with $1 \mathrm{mg} / \mathrm{ml}$ collagenasedispase (Boehringer Mannheim, Mannheim, Germany). ${ }^{2}$ The undigested tissue was separated from the cell suspension by sedimentation and the cells were resuspended in supplemented Iscove's medium after being washed at $600 \mathrm{~g}$ for 10 minutes.

For both suspensions, the numbers of mononuclear cells (MNC) were counted under a Bürker chamber, and the percentage of lymphocytes was estimated by counting them on May-Grünwald Giemsa (azur-eosinemethylene blue solution) stained cytospin smears. On average, the dispersion procedure yielded $3.7 \times 10^{6}$ nucleated cells (range 1.3-6.2 $\times 10^{6}$ ) per pool of six duodenal biopsy specimens, comprising $8-25 \%$ lymphocytes in the epithelium, and $2.8 \times 10^{6}$ nucleated cells (range $1.3-6.1 \times 10^{6}$ ) with $20-40 \%$ lymphocytes in the lamina propria. For six colonic biopsy specimens, the number of nucleated cells recovered was $2 \times 10^{5}$ (range: $1.2-5 \times 10^{5}$ ) with $9-27 \%$ lymphocytes in the epithelium, and $8 \times 10^{5}$ (range $2.5-1.4 \times 10^{5}$ ) with $12-46 \%$ lymphocytes in the lamina propria. Viability, as determined by trypan blue exclusion, was greater than $95 \%$ both for IEL and LPL, from the duodenum and from the colon.

Peripheral blood mononuclear cells (PBMC) were isolated by density gradient centrifugation $\left(760 \mathrm{~g}, 20^{\circ} \mathrm{C}, 30\right.$ minutes) on Lymphoprep (Nycomed, Oslo, Norway).
PHENOTYPIC CHARACTERISATION OF IEL AND LPL Flow cytometric analysis was performed on cells directly resuspended at $1 \times 10^{6} / \mathrm{ml}$ in Iscove's medium supplemented with $10 \% \mathrm{FCS}$ and incubated for 30 minutes at $4{ }^{\circ} \mathrm{C}$ with $10 \mu \mathrm{l}$ anti-CD3 (Leu-4), anti-CD4 (Leu-3a), antiCD8 (Leu-2a), or anti-CD69 (Leu-23) (Becton Dickinson, San José, California, USA). The monoclonal antibodies were directly conjugated either to fluorescein isothiocyanate (FITC), phycoerytrin (PE), or piridinchlorophyll-a-protein (PerCP). Cells incubated with isotype matched irrelevant monoclonal antibody served as negative controls. For this phenotypic characterisation, LPL were obtained by incubation of the mucosal fragments with collagenase type I (Sigma Chemical Co.) for 150 minutes at $37^{\circ} \mathrm{C}$ while stirring continuously. After staining, the cells were washed, and at least 5000 cells were analysed by flow cytometry (FACScan, Becton Dickinson). Spectral overlap between the three fluorochromes used was eliminated by electronic compensation. Lymphocyte populations were gated by forward sideward scatter light and by gating for $\mathrm{CD}^{+} \mathrm{T}$ cells.

CYTOKINE SPECIFIC ELISPOT ASSAY

Cell suspensions were assayed for numbers of cells spontaneously secreting IFN- $\gamma$ or IL- 4 by a two site reverse enzyme linked immunospot (ELISPOT) technique using epitope specific mouse antihuman IFN- $\gamma$ or IL- 4 monoclonal antibodies as capture and developing reagents (IFN- $\gamma$ : Chromogenix, Stockholm, Sweden; IL-4: Mabtech AB, Stockholm, Sweden). Briefly, individual wells of nitrocellulose bottomed 96 well millititre HA plates (MAHAN 4550, Millipore, Eschborn, Germany) were coated at $37^{\circ} \mathrm{C}$ for three hours with $100 \mu \mathrm{l}$ of a $10 \mu \mathrm{g} / \mathrm{ml}$ solution of anti-IFN- $\gamma$ (clone $1 / \mathrm{D} 1 \mathrm{~K}$ ) or anti-IL-4 (clone 82-2). After the plates were washed five times with phosphate buffered saline (PBS), blotted dry, blocked with 100 $\mu \mathrm{l} /$ well PBS containing $1 \%$ (wt/vol) bovine serum albumin (BSA), $10 \% \mathrm{FCS}$, and $2 \%$ (wt/ vol) milk powder for one hour at $37^{\circ} \mathrm{C}$, washed again five times with PBS, and blotted dry again, $100 \mu \mathrm{l}$ of different concentrations of cell suspensions $\left(5 \times 10^{4}\right.$ to $20 \times 10^{4} \mathrm{MNC} /$ well $)$ in complete medium was added into the coated wells. The plates were incubated in $5 \% \mathrm{CO}_{2}$ for 20 hours at $37^{\circ} \mathrm{C}$. After incubation, the plates were thoroughly washed 10 times with PBS$0.05 \%$ Tween 20 to remove the cells, and then incubated for three hours at room temperature with $100 \mu \mathrm{l} /$ well of biotinylated anti-IFN- $\gamma$ (3 $\mu \mathrm{g} / \mathrm{ml}$; clone $7 / \mathrm{B} 6 / 1)$ or anti-IL-4 $(1 \mu \mathrm{g} / \mathrm{ml}$; clone 12-1) in PBS-Tween. After washing the plates at least five times with PBS-Tween, extravidin-horseradish peroxidase (Sigma; 2 $\mu \mathrm{g} / \mathrm{ml}$ in PBS- $0.05 \%$ Tween) was added for one hour. After washing five times with PBS, the enzyme-substrate solution was added (3amino-9-ethylcarbazole, AEC; Sigma). Spots appeared after a few minutes, and the reaction was stopped by briefly washing the plates with 
Table 1 Phenotype of intraepithelial (IEL) and lamina propria (LPL) T lymphocytes from normal human gut

\begin{tabular}{llllll}
\hline & \multicolumn{2}{l}{$T$ cell markers } \\
\cline { 2 - 5 } Cell suspension & $C D 4^{+}$ & $C D 8^{+}$ & $C D 4^{+} C D 8^{+}$ & $C D 4^{-} C D 8^{-}$ & $C D 69^{+}$ \\
\hline $\begin{array}{l}\text { Duodenum } \\
\text { IEL }\end{array}$ & $12 \%(5-21)$ & $76 \%(50-93)$ & $5 \%(3-12)$ & $14 \%(3-32)$ & $96 \%(92-100)$ \\
$\quad$ LPL & $45 \%(30-74)$ & $62 \%(45-71)$ & $6 \%(0-14)$ & $7 \%(5-15)$ & $93 \%(86-97)$ \\
Colon & $46 \%(21-55)$ & $50 \%(31-61)$ & $3 \%(1-5)$ & $17 \%(8-32)$ & $83 \%(65-90)$ \\
$\quad$ IEL & $46 \%(41-53)$ & $48 \%(30-56)$ & $3 \%(2-3)$ & $17 \%(12-20)$ & $76 \%(72-80)$ \\
LPL & $480)$ &
\end{tabular}

${ }^{\star}$ Expressed as percentages of $\mathrm{CD}^{+}$cells. Results obtained by flow cytometric analysis are shown as medians (ranges). Triple immunofluorescence allowed counting of both the $\mathrm{CD}^{+} / \mathrm{CD}^{+} / \mathrm{CD}^{+}$and the $\mathrm{CD} 3^{+} / \mathrm{CD} 4^{-} / \mathrm{CD} 8^{-}$lymphocytes.

tap water. Spots were counted under low magnification $(\times 40)$ and recorded as the number of secreting cells (SC) per $10^{5}$ lymphocytes.

\section{PREPARATION OF T LYMPHOCYTE}

SUBPOPULATIONS

To deplete the intestinal MNC suspensions of cell subsets, different cell suspensions were prepared by negative or positive selection techniques using monoclonal antibodies attached to immunomagnetic beads. $\mathrm{CD}^{+}$or $\mathrm{CD} 8^{+}$ lymphocytes were selected with magnetic microspheres directly coated with antibodies to either CD4 or CD8 (Dynabeads M-450 CD4 and Dynabeads M-450 CD8, Dynal, Oslo, Norway). The intestinal MNC were incubated for 30 minutes at $4^{\circ} \mathrm{C}$ with the antibody coated bead preparations. Cells attached to beads and free beads were then retained by applying a magnetic field. Unbound cells were washed twice and resuspended in complete medium. $\mathrm{CD} 4^{+}$or $\mathrm{CD}^{+}$lymphocytes attached to the beads were then detached using immunomagnetic beads coated with antimouse IgG (De-

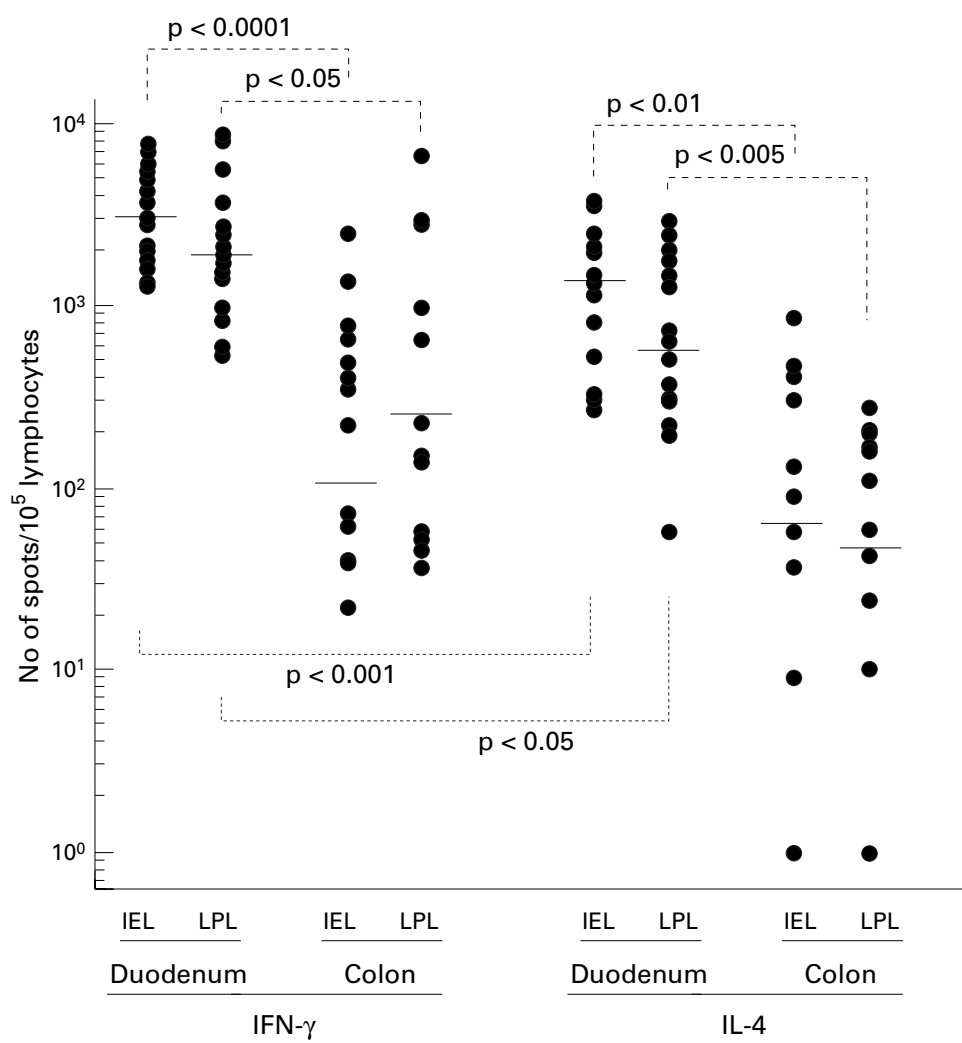

Figure 1 Numbers of IFN- $\gamma$ and/or IL-4 secreting cells per $10^{5}$ lymphocytes within IEL and LPL cell suspensions obtained from normal human intestinal duodenal and colonic mucosae. Individual results are shown and horizontal bars indicate the medians. tachabead, Dynal, Oslo, Norway). Intestinal MNC suspensions underwent this depletion procedure twice, yielding MNC suspensions that contained less than $5 \%$ and less than $15 \%$ of residual contaminating $\mathrm{CD} 4^{+}$or $\mathrm{CD}^{+}$cells, respectively, in the positively selected and in the depleted subpopulation, as controlled by FACS analysis.

FLOW CYTOMETRIC ANALYSIS OF INTRACELLULAR IFN- $\gamma$

Analysis was performed on cells resuspended at $1 \times 10^{6} / \mathrm{ml}$ in Iscove's medium supplemented with $10 \%$ FCS and prestimulated with phorbol myristate acetate (PMA; $10 \mathrm{ng} / \mathrm{ml}$; Sigma) and calcium ionophore A23187 (100 ng/ml; Eurobiochem, Belgium) in the presence of brefeldin A $\left(10 \mu \mathrm{g} / \mathrm{ml}\right.$; Sigma) for four hours at $37^{\circ} \mathrm{C}$ in a humidified incubator at $5 \% \mathrm{CO}_{2}$. For each sample to be analysed $(100 \mu$ of cell suspension), $5 \mu 1$ of anti-CD3 or anti-CD8 (Becton Dickinson) was added, incubated for 20 minutes $\left(4^{\circ} \mathrm{C}\right)$, and washed, followed by incubation with $80 \mu \mathrm{l}$ of reagent A (Fixation Medium, Cell Permeabilisation Kit, AN DER GRUB, Austria) (15 minutes at $20^{\circ} \mathrm{C}$ ). Reagent B ( $80 \mu \mathrm{l}$; Permeabilization Medium) was then added with $5 \mu \mathrm{l}$ of anti-IFN- $\gamma$ (clone 25723.11, Becton Dickinson), and the mixture was incubated for 15 minutes at $20^{\circ} \mathrm{C}$; control isotypes were tested in parallel. Cells were finally resuspended in PBS for immediate analysis by flow cytometry (FACScan, Becton Dickinson). Lymphocytes were gated by forward sideward scatter light and by gating for $\mathrm{CD} 3^{+} \mathrm{T}$ cells.

STATISTICAL ANALYSIS

Tests for significance of differences were performed using the Mann-Whitney U test.

\section{Results}

PHENOTYPIC CHARACTERISATION OF IEL AND LPL SUSPENSIONS

FACS analysis was used to enumerate $\mathrm{CD} 4^{+}$, $\mathrm{CD}^{+}$, and $\mathrm{CD} 9^{+}$cells among $\mathrm{CD}^{+}$lymphocytes retrieved from the epithelium (IEL) and the lamina propria (LPL) of normal duodenum and colon. Most $\mathrm{CD}^{+}$cells, both among IEL and among LPL, expressed the early activation antigen CD69, especially in the duodenum. However, the phenotypic features of $\mathrm{CD}^{+}$IEL were slighly different in the colon compared with the duodenum as the proportion of $\mathrm{CD} 4^{+}$IEL was higher within the colonic mucosa (table 1). 
Table 2 Effects of cycloheximide (CHX) on cytokine secreting cells

\begin{tabular}{|c|c|c|c|c|}
\hline \multirow[t]{2}{*}{ Cytokine } & \multirow[t]{2}{*}{$C H X^{\star}$} & \multicolumn{3}{|c|}{$\begin{array}{l}\text { No of secreting cells } / 10^{5} \\
\text { lymphocytes }\end{array}$} \\
\hline & & $\operatorname{Exp} 1$ & $\operatorname{Exp} 2$ & $\operatorname{Exp} 3$ \\
\hline \multirow[t]{3}{*}{ IFN- $\gamma$} & - & 1227 & 1136 & 1700 \\
\hline & + & 873 & 1000 & 1500 \\
\hline & & $\operatorname{Exp} 4$ & $\operatorname{Exp} 5$ & $\operatorname{Exp} 6$ \\
\hline \multirow[t]{2}{*}{ IL-4 } & - & 2000 & 2358 & 607 \\
\hline & + & 1474 & 2300 & 369 \\
\hline
\end{tabular}

${ }^{\star}$ Cell suspensions were preincubated for four hours at $37^{\circ} \mathrm{C}$ in the absence or presence of CHX $(100 \mu \mathrm{g} / \mathrm{ml})$, before being processed in the ELISPOT plates.

SPONTANEOUS IFN- $\gamma$ AND/OR IL-4 SECRETION BY INTESTINAL LYMPHOCYTES

As assessed by a two site reverse ELISPOT technique, significant numbers of cells spontaneously secreting IFN- $\gamma$ and/or IL-4 were found among intestinal cell suspensions (fig 1). The proportion of secreting cells was always significantly higher among duodenal lymphocytes than among colonic lymphocytes for both cytokines (IFN- $\gamma$ or IL-4) and for the two sites (IEL or LPL) considered. Whereas 3.6\% of IEL and $1.9 \%$ of LPL secreted IFN- $\gamma$ among duodenal lymphocytes, only $0.2 \%$ of colonic lymphocytes, both IEL and LPL, spontaneously secreted IFN- $\gamma$. Interleukin 4 was spontaneously secreted by $1.3 \%$ of IEL and by $0.7 \%$ of LPL in the duodenum, and by only $0.1 \%$ of colonic lymphocytes (IEL and LPL).

In the duodenum, the numbers of IFN- $\gamma \mathrm{SC}$ were significantly higher than the numbers of IL-4 SC both among IEL and LPL (IEL: $\mathrm{p}<0.001$; LPL: $\mathrm{p}<0.05$ ) (fig 1). The ratio (median) between IFN- $\gamma$ SC and IL-4 SC was 3.25 (range 0.7-23) among IEL and 1.90 (range 0.4-33) among LPL, indicating that the physiological balance comprises a higher number of IFN- $\gamma$ SC compared with IL-4 SC in the majority of healthy individuals, even though there is a wide individual variation in the numbers of cytokine SC.

In contrast to the intestinal lymphocytes, the numbers of cells spontaneously secreting IFN- $\gamma$ among PBMC were extremely low (median 12 per $10^{5}$ cells, range $1-27$ ) while IL-4 SC were undetectable. The secretion of cytokines by intestinal lymphocytes in the absence of any added exogenous stimulus was not induced by the cell dispersion procedure as treatment of PBMC with EDTA and collagenase-dispase did not modify the numbers of IFN- $\gamma$ and/or IL-4 SC (data not shown).

To determine whether the ex vivo secretion of cytokines requires de novo protein synthesis, experiments using cycloheximide ( $\mathrm{CHX}$ ) were performed. Addition of CHX (100 $\mu \mathrm{g} / \mathrm{ml}$; Sigma Chemical Co.) for four hours before and during the incubation in the ELISPOT plates reduced the numbers of IFN- $\gamma$ SC and IL-4 SC by only $12-39 \%$ compared with the control without $\mathrm{CHX}$ (table 2). In contrast, the numbers of IFN- $\gamma$ and/or IL-4 SC among PBMC stimulated with PHA $(10 \mu \mathrm{g} / \mathrm{ml}$; Wellcome, Murex Diagnostics Limited, Dartford, UK) were reduced by more than $90 \%$ in the presence of CHX (data not shown). Taken together, these data indicate that de novo protein synthesis is not required for the in vitro detection of cytokine SC among intestinal cells, suggesting that most cytokine synthesis occurred in vivo.

IFN- $\gamma$ AND/OR IL-4 SECRETION BY INTESTINAL LYMPHOCYTES IN RESPONSE TO IN VITRO POLYCLONAL STIMULATION

To determine whether in vitro activation of the cells could further increase the numbers of detectable cytokine SC, duodenal cell suspensions from three patients were either directly processed within the ELISPOT plates or stimulated in vitro with PMA and calcium ionophore A23187 (10 ng/ml and $100 \mathrm{ng} / \mathrm{ml}$ respectively) before and during the ELISPOT procedure. Preliminary experiments have shown that optimal in vitro activation of the cells required a four hour preincubation with the stimulant. Results shown in table 3 indicate that the numbers of IFN- $\gamma$ SC were significantly increased by an in vitro polyclonal activation of the cells, both within IEL and LPL. In contrast, the numbers of IL-4 SC did not increase after in vitro polyclonal stimulation. Control experiments performed on cells preincubated for four hours in the absence of any stimulation showed undetectable or very low numbers of spontaneous cytokine SC compared with cell suspensions directly processed within the ELISPOT plates, further suggesting that most cytokine synthesis detected in the absence of in vitro stimulation reflects the in vivo situation.

\section{PHENOTYPIC CHARACTERISATION OF CYTOKINE} SECRETING CELLS

The phenotype of the intestinal cells spontaneously secreting cytokines was characterised by applying the ELISPOT technique on intestinal cell suspensions depleted or enriched in different subpopulations by using immunomagnetic beads coated with monoclonal antibodies. In preliminary experiments, combined removal of $\mathrm{CD}^{+}$and $\mathrm{CD}^{+}$cells from the intestinal $\mathrm{MNC}$ suspensions resulted in the disapperance of

Table 3 Cytokine secretion by intestinal lymphocytes in response to in vitro polyclonal stimulation

\begin{tabular}{|c|c|c|c|c|c|c|}
\hline \multirow[b]{3}{*}{ Preincubation } & \multicolumn{6}{|c|}{ No of IFN- $\gamma$ secreting cells $/ 10^{5}$ lymphocytes } \\
\hline & \multicolumn{3}{|l|}{$I E L$} & \multicolumn{3}{|l|}{$L P L$} \\
\hline & None & Medium & PMA-ionophore & None & Medium & PMA-ionophore \\
\hline Exp 1 & 724 & 0 & 1384 & 437 & 0 & 12699 \\
\hline Exp 2 & 236 & 0 & 12935 & 61 & 0 & 6571 \\
\hline Exp 3 & 620 & 135 & 6454 & 252 & 94 & 3843 \\
\hline
\end{tabular}

IFN- $\gamma$ secretion was analysed by processing the cells directly in the ELISPOT plates or by preincubating the cells for four hours at $37^{\circ} \mathrm{C}$ in medium alone or in the presence of PMA-ionophore. 
Table 4 Phenotypic characterisation of cytokine secreting cells

\begin{tabular}{|c|c|c|c|c|}
\hline & \multicolumn{4}{|c|}{ No of secreting cells $/ 10^{5}$ lymphocytes } \\
\hline & \multicolumn{2}{|c|}{$I F N-\gamma$} & \multicolumn{2}{|l|}{$I L-4$} \\
\hline & $I E L$ & $L P L$ & $I E L$ & $L P L$ \\
\hline Untreated & 1871 & 791 & 175 & 272 \\
\hline $\begin{array}{l}\text { CD8 and CD4 } \\
\text { depleted }\end{array}$ & 0 & 0 & 0 & 0 \\
\hline Untreated & 1111 & 511 & 1815 & 397 \\
\hline CD8 depleted & 714 & 348 & 1925 & 287 \\
\hline Untreated & 596 & 134 & 409 & 101 \\
\hline CD4 depleted & 28 & 0 & 0 & 0 \\
\hline CD4 enriched & ND & 130 & ND & 55 \\
\hline
\end{tabular}

Results shown for IFN- $\gamma$ and IL-4, for IEL and LPL, and for the three different experimental protocols were obtained from different cell suspensions and are representative of one of three different experiments (untreated/depleted) for each set of data.

IFN- $\gamma$ and/or IL-4 SC both among IEL and LPL, indicating that the secreting cells were $T$ cells (table 4).

Further experiments on $\mathrm{CD} 4^{+}$or $\mathrm{CD}^{+}$cell depleted suspensions were performed to determine the respective roles of $\mathrm{CD}^{+}$and $\mathrm{CD} 8^{+}$ cells in the secretion of cytokines. Depletion of $\mathrm{CD} 4^{+}$cells completely abrogated the detection of cytokine SC except for IFN- $\gamma$ SC among IEL. In contrast, the $\mathrm{CD}^{+}$cell depletion procedure only slightly reduced the number of cytokine SC. To confirm that $\mathrm{CD}^{+}$cells represent the major source of cytokines in the basal state, we also quantified cytokine SC among $\mathrm{CD}^{+}$cell enriched LPL. Both IFN- $\gamma$ and IL-4 SC were recovered within the CD $4^{+}$ cell enriched LPL (table 4). This experiment could not be performed on IEL because of the low numbers of $\mathrm{CD} 4^{+}$cells.

The phenotype of intestinal IFN- $\gamma \mathrm{SC}$ in response to in vitro polyclonal stimulation could be analysed by flow cytometry, a technique which was not sensitive enough to detect the cytokine secretion in the basal state. In response to stimulation with PMA ionophore, IFN $-\gamma$ was synthesised by both $\mathrm{CD} 4^{+}$ and $\mathrm{CD}^{+}$lymphocytes. $\mathrm{CD}^{+}$lymphocytes were the major source of IFN- $\gamma$ within IEL, whereas within LPL, IFN- $\gamma$ was mainly synthesised by $\mathrm{CD}^{+}$lymphocytes (fig 2). Within IEL, $27 \%$ of $\mathrm{CD}^{+}$lymphocytes produced IFN $-\gamma: 16 \%$ were $\mathrm{CD}^{+} / \mathrm{CD}^{+}$and the other $11 \%$ were $\mathrm{CD}^{+} / \mathrm{CD}^{-}$. Within LPL, $65 \%$ of $\mathrm{CD}^{+}$lymphocytes produced IFN- $\gamma$ : $22 \%$ were $\mathrm{CD}^{+} / \mathrm{CD}^{+}$and the other $43 \%$ were $\mathrm{CD}^{+} / \mathrm{CD}^{-}$.

\section{Discussion}

Analysis at the cellular level of IFN- $\gamma$ and IL-4 secretion by human intestinal lymphocytes shows that a substantial proportion of duodenal lymphocytes spontaneously secrete IFN- $\gamma$ and/or IL-4 with a IFN- $\gamma$ SC:IL-4 SC ratio of around 3, both among IEL and LPL. Even if the proportion of cytokine SC was not significantly different in IEL compared with LPL, IEL did not appear to be contaminated by LPL as the phenotypes of the recovered duodenal IEL were quite different from LPL and very similar to those described previously in the literature. ${ }^{15}$
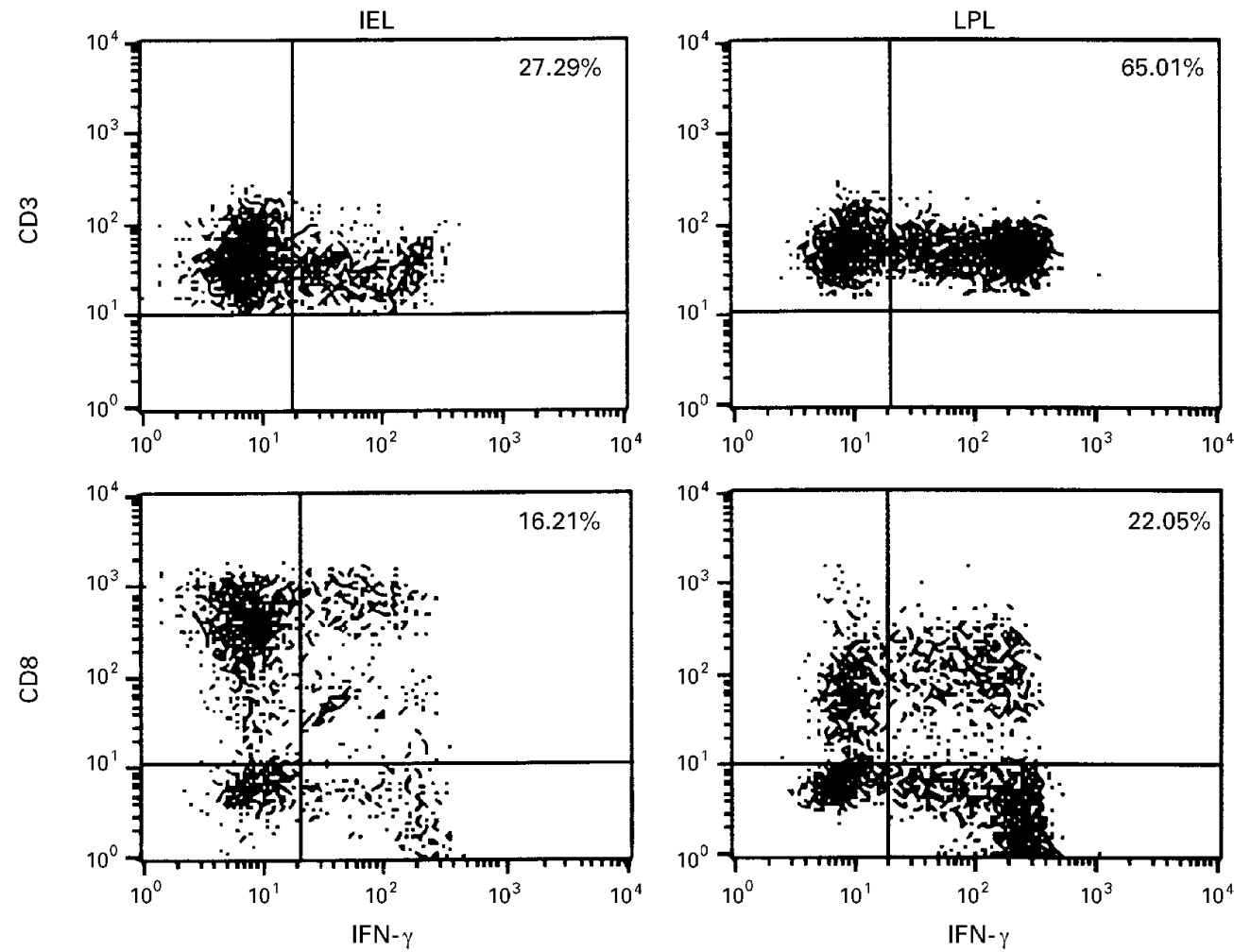

Figure 2 Dot plots from three colour flow cytometric analysis for anti-IFN- $\gamma$ on $C D 3^{+}$and on $C D 8^{+}$or $C D 8^{-}$cells for IEL and LPL. The cells were cultured for four hours with PMA and ionophore $A 23187$ in the presence of brefeldin $A$. The fluorescence plots shown are representative of one of three different experiments and cells analysed were gated for $C D 3^{+}$cells so that results are given as percentage of $\mathrm{CD}^{+}$cells. Control isotype was used to differentiate positive from negative immunofluorescence. 
Cytokine secretion was analysed by the ELISPOT technique which has already been extensively used in animal studies, and which was previously used in humans mainly to analyse IFN- $\gamma$ secretion. ${ }^{216}$ This technique is very sensitive. However, there is no direct correlation between the numbers of SC detectable by ELISPOT and the total amount of cytokine secreted as the spot's size is quite heterogeneous depending on the amount of cytokine released by an individual cell (unpublished data). Although the ELISPOT procedure allows the enumeration of cytokine secreting cells on an ex vivo basis, it is likely that the data obtained reflect the in vivo setting, as inhibition of protein synthesis ex vivo only partially reduced the numbers of cytokine secreting cells.

Results of the cell depletion experiments indicate that $\mathrm{CD}^{+} / \mathrm{CD}^{+} \mathrm{T}$ cells are the main cells spontaneously secreting IFN- $\gamma$ and/or IL-4 within the intestinal mucosa both among IEL and LPL. Even if IEL contain less $\mathrm{CD} 4^{+}$ cells than LPL, the percentages of cytokine SC are not significantly different between IEL and LPL. These results suggest that the proportion of cytokine SC among $\mathrm{CD} 4^{+}$cells is higher in IEL compared with LPL. These cells probably represent memory $\mathrm{T}$ cells that have been activated in vivo as it has been shown that among $\mathrm{CD}^{+} \mathrm{T}$ cells, only memory cells have the capacity to produce IFN- $\gamma$ on mitogen stimulation, ${ }^{17}$ and as phenotype studies have shown that almost all CD $4^{+}$LPL and the majority of IEL express the CD45RO variant of the leucocyte common antigen. ${ }^{15}{ }^{18}$ However, cell depletion experiments suggested that among IEL, IFN- $\gamma$ is not exclusively secreted by $\mathrm{CD} 4^{+}$cells but also partially by $\mathrm{CD} 8^{+}$lymphocytes. As the cytotoxic functions of IEL have clearly been shown, especially in animal studies, ${ }^{19}$ IFN- $\gamma$ synthesised by CD8 cytotoxic $\mathrm{T}$ cells could synergise in the killing of virus infected epithelial cells. In contrast to the spontaneously secreted cytokines, the proportion of IFN- $\gamma$ synthesised by $\mathrm{CD}^{+}$lymphocytes was more important in response to in vitro polyclonal activation, especially among IEL.

Cells spontaneously secreting IFN- $\gamma$ and IL-4 were also identified among colonic lymphocytes, but the numbers of cytokine SC within the colon were significantly lower than within the duodenum, contrasting with the much more abundant flora at this site. The higher percentage of $\mathrm{CD} 4^{+}$lymphocytes in the colonic compared with the duodenal epithelium might also have led to the assumption that a greater percentage of cytokine SC would be present in the colonic epithelium, but this was not the case. However, some caution is needed in the interpretation of the phenotypic analysis of colonic mucosa due to possible contamination by cells from lymphoid follicles. ${ }^{20}$

The presence of significant numbers of cells spontaneously secreting cytokines among intestinal lymphocytes suggests that at least a proportion of them are in a constant state of immune activation, especially among duodenal IEL. From data in tables 1 and 4 we may extrapolate the proportion of cytokine SC among the $\mathrm{CD}^{+}$IEL. This proportion is up to $20 \%$ for IFN- $\gamma$ (considering that $65 \%$ of IFN- $\gamma$ $\mathrm{SC}$ are $\mathrm{CD}^{+}$cells) and up to $11 \%$ for IL-4 (considering that $\mathrm{CD}^{+}$cells are the main source of IL-4). CD69 expression on the vast majority of duodenal lymphocytes and on a high proportion of colonic lymphocytes suggests that antigen stimulation in the gut is persistent or very frequent, since CD69 expression on the surface of $\mathrm{T}$ cells has been shown to be rapidly lost if the stimulus is withdrawn. ${ }^{21}$ HLA-DR expression has also been reported on most duodenal IEL suggesting that these cells are activated in vivo. ${ }^{22}$ However, the expression of these activation markers on the majority of intestinal lymphocytes, especially duodenal IEL, is in contrast to the proportion of cells spontaneously secreting cytokines and to the numbers of intestinal lymphocytes expressing IL-2 receptor $\left(\mathrm{CD} 25^{+}\right)$as a marker of $\mathrm{T}$ cell activation. In normal conditions, CD25 antigen is not expressed on $\mathrm{IEL}^{22}$ and is only expressed on few lamina propria $\mathrm{T}$ cells. ${ }^{23}$

These data suggest that cytokine secretion and CD69 expression at the cell surface measure qualitatively distinct properties of activated cells. Signalling requirements for the induction of cytokine synthesis might be more stringent than those required for the induction of CD69 expression. In this way, cells that are partially activated might express CD69 but fail to go on to cytokine synthesis as it has been previously reported that not all $\mathrm{CD} 69^{+}$lymphocytes go on to proliferate. ${ }^{24}$ Nevertheless, these cells are capable of rapid activation of cytokine secretion once appropriate signals are received, as shown by the rapid increase in the numbers of IFN- $\gamma$ SC after short in vitro activation with PMA plus A23187.

The precise biological role of the continuous in vivo cytokine production by a relatively high proportion of intestinal lymphocytes is not known. The presence of a significant proportion of lymphocytes containing IFN- $\gamma$ in the small bowel mucosa has already been reported by others but this was generally determined by immunohistochemical methods or by cytokine mRNA detection and therefore did not necessarily reflect protein secretion. ${ }^{134}$ The detection of IL-4 mRNA and protein was only very recently reported by Beckett et $a l^{13}$ in the normal human jejunal lamina propria. By using the ELISPOT technique, we were able to enumerate cells spontaneously secreting IFN- $\gamma$ and/or IL-4 and to determine the ratio between IFN- $\gamma$ SC and IL-4 SC, IL-4 producing cells being three times less numerous than IFN- $\gamma$ SC. However, we were not able to determine whether activated $\mathrm{T}$ cells were producing both IFN- $\gamma$ and IL-4, or whether each cytokine was produced by a different $T$ cell subset. The balance between the numbers of IFN- $\gamma \mathrm{SC}$ and IL-4 SC in the intestinal mucosa might be quite important for normal intestinal homoeostasis as the relative frequencies of these cells might determine the isotype of specific responses induced by exogenous antigens occurring in mucosal tissue. ${ }^{25}$ In contrast, disturbance of the ratios between these numbers 
could play a role in the pathogenesis of certain gastrointestinal diseases as these cytokines probably play a role both in control of the physiological functions of the epithelium, and in regulation of the immune response. The normal expression of MHC class II antigens by small bowel enterocytes, compared with their absence on colonic enterocytes, could be a consequence of the $\mathrm{T}$ cell secretion of IFN- $\gamma$ by a high proportion of duodenal $\mathrm{CD} 4^{+}$ lymphocytes and only by a low number of colonic $\mathrm{CD} 4^{+}$lymphocytes. ${ }^{26}{ }^{27}$

In summary, we have shown that the majority of intestinal $\mathrm{T}$ cells express activation markers under physiological conditions and that a significant proportion of them spontaneously secrete IFN- $\gamma$ and/or IL-4, especially within duodenal epithelium. These cytokines are probably involved in normal homoeostasis of the human intestinal mucosa and disturbances of the ratios between these two cytokines could play a role in the pathogenesis of gastrointestinal diseases.

The authors thank Dr A Schmit and Dr F Roufosse for their critical reading of the manuscript. This study was supported by the Fonds National de la Recherche Scientifique (FRSM), Belgium.

1 Lundqvist C, Melgar S, Mo-Wai Yeung M, et al. Intraepithelial lymphocytes in human gut have lytic potential and a cytokine profile that suggest Thelper 1 and cytotoxic functions. F Immunol 1996;157:1926-34

2 Quiding M, Nordström I, Kilander A, et al. Intestinal immune responses in humans. Oral cholera vaccination induces strong intestinal antibody responses and interferon- $\gamma$ production and evokes local immunological memory. F Clin Invest 1991;88:143-8.

3 Kontakou M, Sturgess RP, Przemioslo RT, et al. Detection of interferon gamma mRNA in the mucosa of patients with coeliac disease by in situ hybridisation. Gut 1994;35:1037Al-

4 Al-Dawoud A, Nakshabendi I, Foulis A, et al. Immunohistochemical analysis of mucosal gamma-interferon production in coeliac disease. Gut 1992;33:1482-6.

5 Holmgren J, Fryklund J, Larsson H. Gamma-interferonmediated down-regulation of electrolyte secretion by intestinal epithelial cells: a local immune mechanism. Scand $\mathcal{f}$ tinal epithelial cells: a local

6 Sollid LM, Kvale D, Brandtzaeg P, et al. Interferon- $\gamma$ enhances expression of secretory component, the epithelial receptor for polymeric immunoglobulin. F Immunol 1987; 138:4303-6.

7 Trinchieri G, Perussia B. Immune interferon: a pleiotopic lymphokine with multiple effects. Immunol Today 1985;6: $131-6$.

8 Powrie F, Menon S, Coffman RL. Interleukin-4 and interleukin-10 synergize to inhibit cell-mediated immunity in vivo. Eur F Immunol 1993;23:2223-9.

9 Kühn R, Löhler D, Rennick D, et al. Interleukin-10deficient mice develop chronic enterocolitis. Cell 1993;75: 263-74.
10 Targan AR, Deem RL, Liu M, et al. Definition of a lamina propria $T$ cell responsive state. Enhanced cytokine responsiveness of T cells stimulated through the CD2 pathway. $\mathcal{F}$ Immunol 1995;154:664-75.

11 Fuss IJ, Neurath M, Boirivant M, et al. Disparate CD4+ lamina propria (LP) lymphokine secretion profiles in inflammatory bowel disease. Crohn's disease LP cells manifest increased secretion of IFN- $\gamma$, whereas ulcerative colitis LP cells manifest increased secretion of IL-5. F Immunol 1996;157:1261-70.

12 West GA, Matsuura $\mathrm{T}$, Levine $\mathrm{AD}$, et al. Interleukin 4 in inflammatory bowel disease and mucosal immune reactivity. Gastroenterology 1996;110:1683-95.

13 Beckett CG, Dell'Olio D, Kontakou M, et al. Analysis of interleukin-4 and interleukin-10 and their association with the lymphocytic infiltrate in the small intestine of patients with coeliac disease. Gut 1996;39:818-23.

14 Mosley RL, Klein JR. A rapid method for isolating murine intestine intraepithelial lymphocytes with high yield and purity. F Immunol Methods 1992;156:19-26.

15 Jarry A, Cerf-Bensussan N, Brousse N, et al. Subsets of $\mathrm{CD}^{+}(\mathrm{T}$ cell receptor $\alpha \beta+$ or $\gamma \delta+)$ and $\mathrm{CD} 3^{-}$lymphocytes isolated from normal human gut epithelium display phenotypical features different from their counterparts in peripheral blood. Eur f Immunol 1990;20:1097-103.

16 Taguchi T, McGhee JR, Coffman RL, et al. Analysis of Th1 and Th2 cells in murine gut-associated tissues. Frequencies of $\mathrm{CD}^{+}$and $\mathrm{CD} 8^{+} \mathrm{T}$ cells that secrete IFN- $\gamma$ and IL-5. $\mathcal{F}$ Immunol 1990;145:68-77.

17 Ehlers S, Smith KA. Differentiation of T-cell lymphokine expression: the in vitro acquisition of T-cell memory. $\mathcal{F}$ Exp Med 1991;173:25-36.

18 Harvey J, Jones DB, Wright DH. Leucocyte common antigen expression on $\mathrm{T}$ cells in normal and inflamed human gut. Immunology 1989;68:13-17.

19 Guy-Grand D, Malassis-Seris M, Briottet C, et al. Cytotoxic differentiation of mouse gut thymodependent and independent intraepithelial $\mathrm{T}$ lymphocytes is induced locally. Correlation between functionnal assays, presence of perforin and granzyme transcripts, and cytoplasmic granules. 7 Exp Med 1991;173:1549-52.

20 Trejdosiewicz LK. Intestinal intraepithelial lymphocytes and lymphoepithelial interactions in the human gastrointestinal mucosa. Immunol Lett 1992;32:13-20.

21 Testi R, Philips JH, Lanier LL. Leu 23 induction as an early marker of functional $\mathrm{CD} 3 / \mathrm{T}$ cell antigen receptor triggering. Requirement for receptor cross-linking, prolonged elevation of intracellular $[\mathrm{Ca}++]$ and stimulation of protein kinase C. F Immunol 1989;142:1854-60.

22 Abuzakouk M, Kelleher D, Feighery C, et al. Increased HLA-DR and decreased CD 3 on human intestinal intraepithelial lymphocytes: evidence of activation? Gut 1996;39:396-400.

23 Halstensen TS, Brandtzaeg P. Activated T lymphocytes in the celiac lesion: non-proliferative activation (CD25) of $\mathrm{CD} 4+\alpha / \beta$ cells in the lamina propria but proliferation ( $\mathrm{Ki}-$ $67)$ of $\alpha / \beta$ and $\gamma / \delta$ cells in the epithelium. Eur $\mathcal{F}$ Immunol 1993;23:505-10.

24 Simms P, Ellis T. Utility of flow cytometry detection of CD69 expression as a rapid method for determining polyand oligoclonal lymphocyte activation. Clinical Diagnostic Laboratory Immunology 1996;3:301-4.

25 Mosmann T, Coffman R. TH1 and TH2 cells: different patterns of lymphokine secretion lead to different functional properties. Annu Rev Immunol 1989;7:145-73.

26 Lundqvist C, Baranov V, Hammarström S, et al. Intraepithelial lymphocytes. Evidence for regional specialization and extrathymic $\mathrm{T}$ cell maturation in the human gut epithelium. Int Immunol 1995;7:1473-87.

27 Sollid LM, Gaudernack G, Markussen G, et al. Induction of various HLA class II molecules in a human colonic adenocarcinoma cell line. Scand F Immunol 1987;25:175-80. 